\title{
Dini İnanışlara Göre Doğurganlığı Etkileyen Faktörlerin Etkileşim Hipotezi Açısından Araştırılması
}

\section{Investigation of the Factors Affecting Fertility in terms of Interaction Hypothesis According to Religious Beliefs}

\author{
Prof. Dr. Sibel SELIM ${ }^{\left({ }^{1}{ }_{1}\right.}$, Dr. Derya BİLINiN ${ }_{2}$
}

\begin{abstract}
$\ddot{\mathbf{O} z}$
Gelir, çocuk maliyetleri, ailelerin tercihleri, doğurganlık üzerinde etkili olan başlıca faktörler olmakla birlikte din, dil, yaş gibi faktörler de doğurganlık üzerinde etkilidir. Ailelerin tercihlerinde etkili olan faktörlerden dini inancın, ailelerin sahip oldukları çocuk sayısı üzerine olan etkisinin; evlilik, doğum kontrol yöntemlerinin kullanımı, kürtaj, istenilen aile büyüklüğü, boşanma ve cinsiyet rolleri ile ilgili normlar aracılığıyla olduğu düşünülmektedir. Bazı dinlerde aile bütünlüğünün korunması amacıyla sıkı kurallar yer almakta ve boşanma, kürtaj gibi çocuk sayısını azaltan davranışlar yasaklanmaktadır. Bu bağlamda, farklı dini inanışlara sahip bireylerin doğurganlık davranışına yönelik geliştirilen pek çok hipotez söz konusudur. Bu hipotezler, karakteristikler hipotezi, özelleştirilmiş teoloji hipotezi, azınlık grubu statüsü hipotezi ve etkileşim hipotezidir. Bu çalışmada amaç, Dünya Değerler Anketi 2010- 2014 verileri kullanılarak Müslüman, Hristiyan ve Musevi dini inanışa sahip bireylerin doğurganlıklarını etkileyen faktörlerin etkileşim hipotezi açısından sayma (count) veri regresyon modeli ile araştırılmasıdır. Bu çalışmadan elde edilen bulgulara göre, dini inanışlar açısından doğurganlık farklılıkları bulunmaktadır. Ayrıca, Müslüman ve Hristiyan dini inanışında hem dini hem de sosyo-ekonomik değişkenlerin doğurganlık üzerinde etkili olmasından dolayı etkileşim hipotezi geçerli olduğu sonucu ortaya çıkmıştır.
\end{abstract}

Anahtar Kelimeler: Doğurganlık, dini inanış, etkileşim hipotezi, sayma veri modelleri

Makale Türü: Araştırma

\begin{abstract}
Although income, child costs, family preferences, are the main factors affecting fertility, factors such as religion, language, age, etc. also affect fertility. The effect of religious belief on the number of children of families, which is one of the factors that affect families' preferences; It is thought to be through norms related to marriage, the use of birth control methods, abortion, desired family size, divorce and gender roles. Some religions have strict rules for the protection of family integrity, and behavior that reduces the number of children, such as divorce and abortion is prohibited. In this context, there are many hypotheses developed for the fertility behavior of individuals with different religious beliefs. These hypotheses are the characteristics hypothesis, the particularized theology hypothesis, the minority group status hypothesis and the interaction hypothesis. The aim of this study is to investigate the factors affecting the fertility of people with Muslim, Christian and Jewish religious beliefs using the data regression model using the World Values Survey 2010-2014 data. According to the findings obtained from this study, there are differences in fertility in terms of religious beliefs. In addition, the interaction hypothesis is valid in the Muslim and Christian religious beliefs because both religion and socio-economic variables are effective on fertility.
\end{abstract}

Keywords: Fertility, religious beliefs, interaction hypothesis, count data models

Paper Type: Research

\footnotetext{
${ }^{1}$ Manisa Celal Bayar Üniversitesi, İktisadi ve İdari Bilimler Fakültesi, sibel.selim@ @ cbu.edu.tr.

${ }^{2}$ Manisa Celal Bayar Üniversitesi, Sosyal Bilimler Enstitüsü, deryabilgin836@ gmail.com.
}

Atıf için (to cite): Selim, S. ve Bilgin, D. (2020). Dini inanışlara göre doğurganlığı etkileyen faktörlerin etkileşim hipotezi açısından araştırılması. Afyon Kocatepe Üniversitesi Sosyal Bilimler Dergisi, 22(4), 1005-1019. 


\section{Giriş}

1960'lı yıllara kadar ekonomistler doğurganlığı belirleyen etmenlerin ekonominin kapsamı dışında olduğuna inanmışlardır. Bu düşüncenin temelinde ise doğurganlığın kesin olarak geleneksel tüketici tercihleri teorisi kapsamına alınmasındaki zorluk yer almaktadır. Doğurganlık davranışının birçok özelliği doğurganlığın teorik çerçevede analiz edilmesini zorlaştırmaktadır (Willis, 1973, s. 16). Bunlar:

-Çocuk dünyaya getirmek ve çocuk yetiştirmek piyasası olmayan aktivitelerdir. Ebeveynler hem çocuk talep eden hem de arz edenlerdir.

-Çocuk ve hanehalkı aktivitelerinin her ikisi de parasal harcamaya ek olarak ebeveyn zamanlarının da harcanmasını gerektirmektedir.

-Ebeveynlerin çocuklara olan yükümlülükleri uzun sürelidir hatta bazen ebeveynlerin yaşam sürelerini de aşmaktadır.

-Çocuk dünyaya getirmenin ve çocuk yetiştirmenin ebeveynler açısından zamansal ve parasal harcamaları, aileden aileye ve kültürden kültüre çeşitlilik göstermektedir. Bu durumda ebeveynlerin çocuklarına olan yükümlülüklerinin, dişsal bir çocuk başına harcama programı tarafından belirlenmesine ihtiyaç duyulmamaktadır.

-Çocuk sahibi olmanın nedeni hem çocukların ebeveynlerine sağlamaları beklenen doğrudan tatmin hem de aile işinde çalışmaları veya ailelerine parasal yardım yapmaları ile sağlanabilecek olan dolaylı tatmin olabilir. Yani doğurganlık; tüketim, tasarruf veya yatırım düşünceleriyle motive edilmektedir.

-Ebeveynler dünyaya getirecekleri ve yetiştirecekleri çocuk sayısı ve zamanlaması üzerinde doğrudan kontrolü sağlayamaz.

-Çocuk sahibi olmaya karar verme, evlenme yaşı ve evlenilecek partnerin özellikleri konusunda karar verme birbirleri ile yakından ilişkilidir. Dahası, çocuk yapmaya karar verme ile birlikte bu özellikler de aile kararları üzerinde bağımsız etki yaratmaktadır.

Beşeri sermaye, zaman dağılımı ve piyasa dışı hanehalkı davranışını açıklamaya yönelik ekonomik teorideki gelişmeler, doğurganlığın gelir, tasarruf, tüketim, işgücü davranışı gibi diğer geleneksel ekonomik değişkenlerle birlikte analizini mümkün kılmıştır (Willis, 1973, s. 15). Modern doğurganlık teorisinde çocuk talebinin; ailenin gelirine, ebeveynlerin zamanlarının değerine (özellikle annenin), çocuk kalitesine ve diğer aile değişkenlerine bağlı olduğu gösterilmiştir (Becker, 2009, s. 2).

Doğurganlığın ekonomik çerçeve kapsamında ele alınması Becker (1960) ile başlamıştır. Becker (1960)'a göre birçok anne ve baba açısından çocuklar fiziksel gelir veya tatmin kaynağ olmaktadır. Bu doğrultuda ekonomik açıdan çocuklar dayanıklı tüketim malları olarak değerlendirilirlerken parasal gelir sağladıkları durumlarda ise üretim malı olarak değerlendirilmektedirler. Çocukların dayanıklı tüketim malları olarak ele alınmasında çocukların fayda sağladıkları varsayılmakta ve elde edilen bu faydanın diğer tüketim malları ile karşılaştırılması farksızlık eğrileri ile yapılmaktadır. Farksızlık eğrilerinin şekli, çocukların göreceli tercihi veya başka bir deyişle "zevkler" tarafından belirlenmektedir. Bu zevkler, sırayla, bir ailenin dini, 1rk1, yaşı ve benzerleri tarafından belirlenebilmektedir.

Din, bireyin günlük yaşamlarını, değerlerini, tutumlarını, davranışlarını, inanç ve ilkelerini toplumsal ilişkiler içinde düzenlemeye çalışmaktadır. Dini inancın etkilerini hayatın her alanında görmek mümkündür. Dinlerin özellikle kadınlara yüklediği rol; kadının doğurganlık özelliğini ön plana çıkarmakta ve buna yönelik kurallar içermektedir. McQuillan (2004)'da belirtildiği gibi dinin toplumsal hayatı ve doğurganlığg etkilemesinde üç ana unsur ön plana çıkmaktadır. Bunlardan birincisi kürtaj, kısırlaştırma, doğum kontrolü gibi doğurganlığın yakın belirleyicilerine ilişkin düzenleyici kurallar ve normları açıkça belirtmesidir. İkincisi, insanları dini öğretilere uymaya zorlayacak ve bu öğretileri iletecek araçlara sahip olmasıdır. Kurallara uymayanlara karşı resmi olmayan bir şekilde toplumsal baskı söz konusuyken dini inançla birlikte uymayanlara ceza, uyanlara ödül verilmesini sağlayan resmi örgütlenme oluşmuştur. Üçüncüsü 
ise dini inancın inananların sosyal kimliklerinin önemli bir bileşeni olması nedeniyle sosyal tercihlerini dini öğretiler doğrultusunda yapmalarıdır. Doğurganlık ve din arasındaki ilişki ele alındığında farklı dini inanışlara sahip bireylerin doğurganlık davranışına yönelik geliştirilen pek çok teori ve hipotezlerin söz konusu olduğu görülür. Bu hipotezler arasında karakteristikler hipotezi, özelleştirilmiş teoloji hipotezi, azınlık grubu statüsü hipotezi ve etkileşim hipotezi öne çıkmaktadır. Literatürde dini inanışlar arasındaki doğurganlık farklılıklarının açıklanmasında ilk üç hipotez yeterli görülmediğinden etkileşim hipotezi ortaya atılmıştır.

$\mathrm{Bu}$ çalışmada sayma veri regresyon modelleri kullanılarak farklı dini inanışlara sahip bireylerin doğurganlık davranışını etkileyen faktörler Müslüman, Hristiyan ve Musevi dini inanışlar açısından etkileşim hipotezi kapsamında incelenmiştir. Bu çalışmada, üç dini inanışın ele alınmasının sebebi, tek tanrılı dinler olarak en fazla mensuba sahip olmalarıdır. Literatürde din ile doğurganlık arasındaki ilişkiyi inceleyen birçok çalışma (bkz. Becker 1977, Lehrer 1996, Heton 2011, Chamie 1971) olmasına rağmen söz konusu üç dini inanışa sahip olan bireylerin etkileşim hipotezi açısından doğurganlığg etkileyen faktörlerin belirlenmesine yönelik bir çalışmaya rastlanılmamıştır. Bu çalışma, dini inanışa göre doğurganlık farklılıklarının ortaya konulması açısından da literatüre katkı sağlayacaktır.

Çalışmanın izleyen bölümleri şu şekilde organize edilmiştir: İkinci bölümde doğurganlık ve din konuları teorik olarak ele alınmış ve din ile doğurganlık arasındaki ilişkinin açıklamasına yönelik hipotezler tanıtılmıştır. Üçüncü bölümde konu üzerine yapılmış literatürdeki çalışmalara yer verilmiştir. Dördüncü bölümde çalışmada kullanılan yöntem hakkında bilgi verilmekte olup beşinci bölümde kullanılan değişkenler, tanımlayıcı istatistikler ve sayma veri regresyon modellerinden elde edilen bulgular yer almaktadır. Bulguların değerlendirildiği sonuç bölümü ise altıncı bölümdür.

\section{Doğurganlık ve Din}

Doğurganlığın ekonomik çerçeve içerisinde ele alınması Becker'ın 1960 yılında yayınladığ çalışma ile başlamıştır. Becker (1960)'a göre birçok aile için çocuklar fiziki gelir ve fayda sağlayan kaynak olup ekonomi terminolojisinde "çocuk" tüketim malı olarak ele alınmaktadır. Bu durumda çocuk talebi; gelir, çocuk maliyeti ve ailelerin zevkleri tarafından belirlenmektedir. Becker (1960)'a göre çocuk talebi ile gelir arasındaki ilişkinin belirlenmesinde ailelerin doğum kontrol bilgisi önemli bir etkendir. Ailelerin sahip olduğu doğum kontrol bilgisi toplumun her kesiminde aynı ise ailenin gelirinde artış yaşanması çocuk talebinde de artışa sebep olmaktadır. Ancak sosyo-ekonomik olarak üst seviyede olan ailelerin modern doğum kontrol yöntemlerine daha kolay ulaşması ve bunun toplumun daha alt seviyelerindeki ailelere ulaşmasının zaman alması gibi sebeplerden dolayı toplumun her kesiminde doğum kontrol bilgisinin aynı olmaması durumunda gelir ile çocuk talebi arasında ters yönlü bir ilişki ortaya çıkmakta ve ailelerin gelirinde artış yaşandığında çocuk talebinde azalma meydana gelmektedir. Çocuk talebini belirleyen etmenlerden bir diğeri olan çocuk maliyetleri çocuk kalitesiyle ilişkilidir. Becker (1960), doğurganlığı bir fayda fonksiyonu içinde ayrı ayrı incelenen çocuk miktarı ve kalitesi arasındaki ters yönlü bir etkileşim ile belirlemektedir. Kalite-miktar ilişkisinin analizi için basit fayda fonksiyonu aşağıdaki gibidir (Becker ve Lewis, 1973, s. 280, Selim ve Üçdoğruk, 2003, s. 14).

$$
\mathrm{U}=\mathrm{U}(\mathrm{n}, \mathrm{q}, \mathrm{y})
$$

Fonksiyon içerisinde "n"; çocuk sayısını, "q" çocukların kalitesini ve "y" diğer tüketim mallarının bileşimini göstermektedir. Bütçe kısıtı fonksiyonu ise;

$$
\mathrm{I}=\mathrm{nq} \pi+\mathrm{y} \pi_{\mathrm{y}}
$$

şeklindedir. "I"gelirin tamamını, " $\pi$ "; "nq"nun fiyatını, " $\pi_{\mathrm{y}}$ " ise diğer tüketim mallarının fiyatını göstermektedir. Bütçe kısıtı altında fayda maksimizasyonu sağlandığında;

$$
\mathrm{MU}_{\mathrm{n}}=\lambda \mathrm{q} \pi=\lambda \mathrm{p}_{\mathrm{n}} ; \mathrm{MU}_{\mathrm{q}}=\lambda \mathrm{n} \pi=\lambda \mathrm{p}_{\mathrm{q}} ; \mathrm{MU}_{\mathrm{y}}=\lambda \pi_{\mathrm{y}}=\lambda \mathrm{p}_{\mathrm{y}}
$$


"p" marjinal maliyetleri ya da gölge fiyatları gösterirken, " $\lambda$ " parasal gelirin marjinal faydasını göstermektedir. Çocuk sayısına bağlı olan gölge fiyatı $\left(\mathrm{p}_{\mathrm{n}}\right)$ çocuk kalitesiyle $(\mathrm{q})$ pozitif ilişkilidir ve çocuk kalitesine bağlı olan gölge fiyatı da $\left(\mathrm{p}_{\mathrm{q}}\right)$ çocuk sayısıyla pozitif ilişkilidir. Çocuk sayısı fazla olduğunda çocuk kalitesinde artışın yaşanması maliyetleri arttırmakta, çocuk kalitesi yüksek olduğunda çocuk sayısının artması maliyetleri arttırmaktadır. Tüketim malı olarak çocuklar ailelerine fayda sağlamaktadır ve çocukların ailelerine sağladığı faydanın diğer tüketim malları ile karşılaştırılması farksızlık eğrileri aracılığıyla yapılmaktadır. Farksızlık eğrilerinin şekli ise din, yaş, ırk gibi değişkenler aracılığıyla da açıklanabilmektedir (Becker, 1960, s. 211).

Kişilerin arzu ettikleri ve gerçekleşen çocuk sayılarının aynı olmasına olanak sağlayan en etkili yöntemler kürtaj ve doğum kontrol teknikleri kullanımıdır. Ancak her üç tek tanrılı dinde çocuk sahibi olmayı engelleyen her türlü tıbbi müdahaleye veya istekli kürtaj gibi uygulamalara karşı çıkılmaktadır. Kadının hamile kalmasına, doğacak çocuğun cinsiyetine ve yaşamının ne kadar olacağına ilişkin süreçlerin tanrı tarafından çocuğun kaderinde yazıldığı kabul edildiği için dinler çocuğu tanrının bir lütfu olarak görmektedir ve buna zarar verecek her türlü davranışı yasaklamaktadır (Karaoğlan ve Duman, 2017, s. 396).

Doğurganlık ve din arasındaki ilişki ele alındığında farklı dini inanışlara sahip bireylerin doğurganlık davranışına yönelik geliştirilen hipotezlerin söz konusu olduğu görülür. $\mathrm{Bu}$ hipotezler arasında karakteristikler hipotezi, özelleştirilmiş teoloji hipotezi, azınlık grubu statüsü hipotezi ve etkileşim hipotezi öne çıkmaktadır (Jones ve Karim 2005: 1-2'den aktaran Jones, 2006, s. 253). Bu hipotezlerden karakteristikler hipotezi, dini gruplar arasındaki farklılıkları konut, sınıf, okul veya diğer sosyoekonomik faktörlerdeki farklılıklara bağlamaktadır. Doğurganlıktaki bu farklılıklar, söz konusu dinlerin belirli öğretilerinden oldukça bağımsız olarak ortaya çıkabilmektedir. Özelleştirilmiş teoloji hipotezi, (İslam örneğinde) pronatalist olarak kabul edilen ve doğum kontrolüne karşı çıkan, dolayısıyla doğurganlığı doğrudan etkileyen özel öğretileri vurgulamaktadır. Doğum kontrol yöntemi kullanımı gelişmekte olan ülkelerde doğurganlık ve din arasında bağdaştırıcı rol oynamaktadır. Özelleştirilmiş teoloji hipotezine göre, doğum kontrol yöntemi kullanımının dini gruplar arasında farklı olmasının en belirgin sebebi doğum kontrolünün bazı dini grup üyeleri tarafından kabul edilmemesidir. Azınlık gruplarının güçlü kolektif kimliğini ve bu kimliği iddia etme ve toplumu güçlendirme arzusu gibi unsurları ön plana çıkaran üçüncü hipotez ise azınlık grubu statüsü hipotezidir. Bu hipotez belirli koşullar dikkate alındığında, azınlık grubu statüsünün güvensizliklerinin doğurganlığı çoğunluk grup seviyelerinin altına düşürdüğünü ileri sürerek dini inanışlar doğrultusunda doğurganlık farklı1ıklarını biraz daha geniş bir bağlama yerleştirmektedir. Etkileşim hipotezinde temel varsayım, tüm dini grupların doğurganlık konusunda sosyo-ekonomik değişimlere benzer şekilde tepki vermesidir (Jones, 2006, s. 253 ve Heaton, 2011, s. 452, Chamie, 1977, s. 365).

$\mathrm{Bu}$ hipotezler arasında karakteristikler hipotezi, tüm bireysel özellikler dikkate alındığında dini inanışın doğurganlık üzerinde etkili olmadığını varsayarken özelleştirilmiş teoloji hipotezi, dini değerler ve öğretiler arasındaki farklılıkların, bireylerin özelliklerini ve dini grupların sosyo-ekonomik profillerini dikkate aldıktan sonra da devam eden doğurganlık farklılıklarına yol açtı̆̆ını varsaymaktadır (Heineck, 2006:2 ve Baudin, 2015, s. 402). Chamie (1981), dini inanışlar arasındaki doğurganlık değişimlerinin açıklanmasında diğer üç hipotezin yeterli olmadığını bu nedenle etkileşim hipotezini geliştirdiğini ileri sürmektedir. Etkileşim hipotezine göre dinler arasındaki doğurganlık farklılaşması iki önemli faktörün fonksiyonudur. Bunlardan ilki, dinlerin dahil oldukları yerel çevreler ve resmi doktrinler, ikincisi ise dini grupların sosyo-ekonomik seviyeleridir. Kısaca, teoriye göre doğurganlık davranışındaki değişim sadece bir dine mensup olmakla açıklanamamaktadır. Dini inanışa göre doğurganlık farklılıkları, dini grupların sosyoekonomik düzeydeki etkileşimlerine ve dahil olunan çevrenin üreme ve doğum kontrolüne ilişkin mevcut ahlaki tutumlarının bir arada değerlendirilmesi ile açıklanabilmektedir. 


\section{Literatür Araștırması}

Doğurganlık ve din konusunda sınırlı olan literatür aşağıda sunulmuştur.

Marcum (1981), 1965 Ulusal Doğurganlık Anketi verilerini kullanarak hazırladığ1 çalışmasında Protestan kadınların doğurganlık davranışını araştırmaktadır. İstenilen ve istenilmeyen doğurganlık için yaptığı analiz sonuçlarında muhafazakâr ve liberal Protestanların istenmeyen doğumlarda dini inanışın düzeyinin etkili olmadığı, muhafazakâr Protestanlarda ise liberal Protestanlara göre daha fazla etkili olduğu sonucuna ulaşılmıştır. 1987-1988 Haneler ve Aileler Ulusal Anketini kullanıldığı Lehrer (1996)'in çalışmasında evliliklerde erkeğin dini inanışının çocuk sahibi olma üzerindeki etkisi araştırılmıştır. İki değerli probit model kullanarak yapılan analizlerde, aynı ve farklı dini inanışa sahip olan evli çiftlere ait veriler kullanılmıştır. Katolik inanışına sahip olan kadınların farklı dini inanışa sahip olan erkekler ile evlenmesinin istenilen çocuk sayısı üzerinde olumsuz etkisi olurken Protestan inanışına sahip kadınlarda ise hiçbir etki söz konusu olmamıştır.

Adsera (2004), 1985 ve 1999 İspanya Doğurganlık Anketi verilerini kullanarak hazırladığı çalışmasında, doğurganlık davranışında dinin önemi hem aile büyüklüğü hem de doğum aralıkları açısından incelenmiştir. Cox oransal hata modelinin kullanıldığı çalışmada, Katolik inancına sahip olan ancak inancin gerektirdiklerini uygulayan ve uygulamayanlarda aile büyüklüklerinin benzer olduğu ve son y1llarda inancın gerektirdiklerini uygulayanlarda doğurganlık oranının arttığı sonuçlarıyla beraber Protestan ve Müslümanların küçük bir grubunun en yüksek doğurganlığa sahip olduğunu ve inançlar arası birlikteliklerde doğurganlığın daha az olduğu sonuçlarına ulaşılmıştır. Heineck (2006), Avusturya Aile ve Doğurganlık Anketi verilerini kullanarak doğurganlık ile dini inanç arasındaki ilişkiyi Poisson Hurdle modelinden yararlanarak açıklamıştır. Yapılan analizlerde Katolik inanışına sahip olan kadınlar ile hiçbir inanışa sahip olmayan kadınlar arasında öngörülen aile büyüklükleri açısından farklar olduğu, hatta dini inanışı yüksek olanlarda bu farkın arttığı sonuçlarıyla beraber dini inanışın çocuk dünyaya getirme zamanına herhangi bir etkisinin olmadığ sonucuna ulaşılmıştır. Adsera (2006), on üç gelişmiş şehirdeki bireylerin beş dini inanışa göre doğurganlı̆̆ 1 ve aile yapısını şekillendirmesini araştırdığ 1 çalışmasında muhafazakâr Protestan ve Katoliklerin ideal çocuk sayılarının, muhafazakâr olmayan Protestanlara ve hiçbir dini inanışı olmayanlara göre daha fazla olduğu sonucuna ulaşmıştır. Özellikle dindar bireylerin, aile yaşamını ve çocuk sahibi olmayı hayatlarında ön plana koyduklarını gözlemlemiştir. Jones (2006), Dünya Bankası ve Birleşmiş Milletler' den elde ettiği verilerle Müslümanlık dini inanışına sahip olan yerlerde doğurganlığın nasıl değişim gösterdiğini araştırmıştır. Elde ettiği sonuçlarda Müslümanların yoğun olduğu yerlerde doğurganlığın düşmeye başladığını bunun arkasında yatan sebebin ise sosyo-ekonomik gelişmeler ve aile planlaması programları kadar Müslümanların doğum kontrol yöntemleri ve kürtaja olan tutumlarından kaynaklandığı sonucuna ulaşmıştır.

Cohen-Zada ve Sander (2008), Genel Toplum Anketi verilerini kullanarak Multinomial logit model aracılığıyla Amerika'da okul seçimlerinde dini inanışın etkisini araştırmışlardır. Katolik, Protestan ve mezhebe üye olmayan okullara yönelik talebe ilişkin gerçekleştirdikleri analizler sonucunda, dini inanışın okul seçiminde etkili bir değişken olduğu, Katoliklerin ve fanatik Protestanların sadece kendi dini inanışlarına yönelik okulları tercih ettikleri sonucuna ulaşmışlardır. Zhang (2008), kadın ve erkeğin dini inanışlarının sahip oldukları çocuk sayısı üzerindeki etkilerini araştırmıştır. 2002 Ulusal Aile Gelişim Anketini kullanarak hazırladığı araştırmasında Poisson regresyon modelinden yararlanmıştır. Amerika Birleşik Devletleri'nde dini inanışın kadın ve erkeğin doğurganlıkları üzerindeki etkisinin çok farklı olmadığı sonucuna ulaşmıştır. Asya, Afrika ve Latin Amerika'daki gelişmekte olan 30 ülkenin Demografik ve Sağlık Anketi verilerinin kullanıldığı Heaton (2011)'ın çalışmasında 5 yaşın altındaki Müslüman/Hristiyan ve Katolik/Protestan çocuk sayısını belirleyen faktörler araştırılmıştır. Poisson regresyon modelinin kullanıldığı çalışmada birçok ülkede Müslüman doğurganlığının Hristiyan doğurganlığından önemli derecede yüksek olduğu fakat Katolik ve Protestanlar arasındaki ortalama farkın küçük olduğu sonucuna ulaşılmıştır. Ayrıca gelişmişlik düzeyi, sosyal 
özellikler ve benzeri belirleyicilerin dini farklılıkta önemli rol oynadığını ancak uluslararası farklılıkları açıklamadığını belirtmişlerdir. Baudin (2015), Fransız Yaşam Tarzı Anketi verileri kullanılarak oluşturmuş olduğu sıfir şişirilmiş Poisson regresyon modelinde Fransa' da Katolikler ve diğer dini gruplar arasındaki doğurganlık farklılıklarını araştırmıştır. Kiliseye giden Katoliklerin gitmeyenlere göre çocuk sayısının daha fazla olduğu ve özelleştirilmiş Katolik ideolojisinin doğurganlık üzerinde etkili olduğu sonucuna ulaşmıştır. Karaoğlan ve Duman (2017), Van ilinde din, toplum ve kadın ile özellikle dinin doğurganlık üzerine olan etkisinin araştırılmasına ilişkisel ve yorumsal değerlendirmelere yer vermişlerdir. Çalışmada, örnekleme dâhil olan dindar kadınların genelde doğurganlık tercihlerinde dini öğretileri referans almadıkları ve bunun da en büyük sebebinin kadınların yükseköğrenim görmüş, meslek sahibi ve işgücünde olmaları ile açıklanabildiğini belirtmişlerdir.

\section{Yöntem}

Sayma veri analizi, belirli bir zaman içerisinde yapılan denemeler sonucunda meydana gelen olayların modellemesine yöneliktir ve bir sayma değişken, negatif olmayan tam sayı değerleri almakla beraber tekrar sayısını içermektedir. Sayma veri modelleri arasında en temel model Poisson regresyon modelidir. Poisson regresyon modeli, açıklayıcı değişkenler ile sayıma dayalı olarak elde edilen çıktı değişkeni arasındaki ilişkiyi açıklamaktadır. Poisson regresyon modeli;

$$
\mathrm{p}(\mathrm{y} ; \mu)=\left\{\frac{e^{-\mu} \mu^{y}}{y !} \quad, \quad \mathrm{y}=0,1,2, \ldots .\right.
$$

şeklindeki Poisson dağılımının ortalamasına göre belirlenmektedir (Cameron ve Trivedi, 1998, s.3'ten aktaran Sezgin ve Deniz; 2004, s. 18).

Poisson dağılımında ortalama ve varyansın eşitliği söz konusudur.

$\mu_{\mathrm{i}}=\mathrm{E}\left(\mathrm{y}_{\mathrm{i}} / \mathrm{x}_{\mathrm{i}}\right)=\mathrm{V}\left(\mathrm{y}_{\mathrm{i}} / \mathrm{x}_{\mathrm{i}}\right)$

Ortalama ve varyansın eşitliği eşit yayılım, varyansın ortalamadan büyük olması aşırı yayılım (overdispersion) ve varyansın ortalamadan küçük olması eksik yayılım (underdispersion) olarak ifade edilmektedir (Selim ve Üçdoğruk, 2003, s. 15; Arı ve Önder, 2013, s. 169).

Poisson regresyon modelinden daha esnek olan Negatif Binom regresyon modeli (NBRM), aşırı yayılım ${ }^{3}$ durumunda Poisson regresyon modeline bir alternatiftir (Wang ve Famoye, 1997, s.274; Rock vd., 2001, s.357). Bu model, PRM'nin "ortalama" parametresini modelleyerek heterojenliği hesaba katmaktadır (Lee vd., 2002, s. 516; Carrivick vd., 2003, s. 55). Gözlenemeyen heterojenlik durumunda olaylar arasındaki pozitif korelasyon aşırı yayılıma yol açmaktadır (Bauer vd., 1999, s. 11). Gözlenemeyen heterojenlik Eşitlik 3'teki gibi bir random etki yoluyla ifade edilmektedir.

$$
\mu=\exp \left(x_{i} \beta+\varepsilon_{i}\right)
$$

$\mathrm{Bu}$ modelde random etki olmasına rağmen $y$ sayma değişkeni hala $\mu$ parametreli Poisson dağılımına sahip olmaktadır. Random etkinin varlığı, y'nin koşullu beklenen değerini değiştirmez. Yani, $\mathrm{E}[\mathrm{y} / \mathrm{x}, \varepsilon]$ ve $\mathrm{E}[\mathrm{y} / \mathrm{x}]$ eşit olmaktadır. Bundan dolayı $\varepsilon$ 'nun dağılımı bilinmese bile $\beta$ 'lar genelleştirilmiş momentler metodu ile tutarlı bir şekilde tahmin edilmektedir (Silva, 1997, s. 219; Selim, 2004).

\section{Ampirik Analiz}

\subsection{Kullanılan Veriler ve Tanımlayıcı İstatistikler}

$\mathrm{Bu}$ çalışmada, mevcut en son veri seti Dünya Değerler Anketi (World Values Survey) 2010-2014 verileri kullanılarak Müslüman, Hristiyan ve Musevi dini inanışlarını benimseyenlerin

\footnotetext{
${ }^{3}$ Aşırı yayılımlı verilerin hipotez testleri için bkz. Breslow, (1990) ve Dean (1992).
} 
sahip oldukları çocuk sayısını etkileyen faktörlerin araştırılmasında sayma veri modellerinden Robust Poisson ve Negatif Binom regresyon modelleri kullanılmıştır. Analizlerde doğurganlık göstergesi olarak ailelerin sahip oldukları çocuk sayısı alınmış ve bağımlı değişken olarak kullanılmıştır. Bağımsız değişkenler ise dini inanca verilen önem, dini hizmetlere katılma sıklığı, bireyin medeni durumu, çalışma durumu, eğitim düzeyi, yaşı, ailenin gelir düzeyi, işteki durumu, hanenin finansal durumundan memnuniyet gibi sosyo-ekonomik göstergelerle birlikte diğer kişilere duyulan güven, yaşam memnuniyeti, çocuğa iyi eğitim verememe endişesi, aileye, işe ve boş zamana verilen önem, yaşanılan yerin nüfus büyüklüğü, sosyal sınıftır.

Şekil 1'de Müslüman, Hristiyan ve Musevi inanışlarını benimseyenlerin ortalama çocuk sayılarının dağılımı görülmektedir. Üç dini inanışa göre ortalama çocuk sayısının en fazla olduğu din Müslümanlıktır. Bunu Hristiyan ve Musevi inanca sahip olanlar izlemektedir.

Şekil 1. Dini inanışlara göre sahip olunan çocuk sayısının dağılımı (\%)

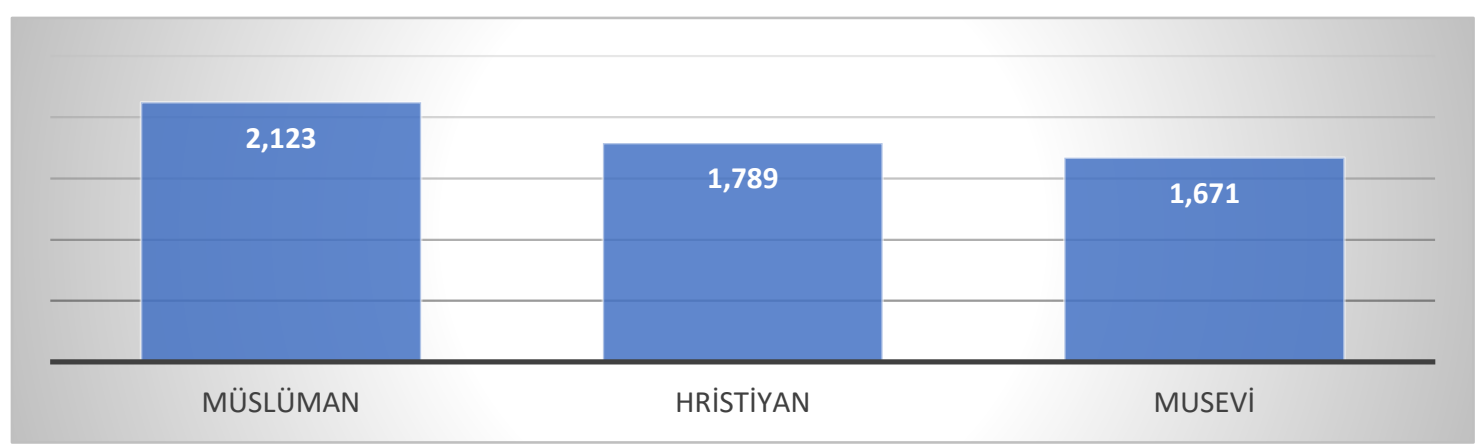

Kaynak: Dünya Değerler Anketi (2010-2014) verileri kullanılarak oluşturulmuştur.

Dini inanca verilen önem derecesine göre sahip olunan çocuk sayılarının yer aldığı Şekil 2 'de ortalama çocuk sayısı en fazla Müslüman inancının çok önemli olduğu cevabını verenlerde görülmektedir. Genel olarak değerlendirildiğinde en az çocuğa sahip olanların dini inanç hiç önemli değil cevabını verenlerde olduğu görülürken en fazla çocuğun ise dini inanç çok önemli cevabını verenlerde olduğu görülmektedir. Her üç dini inanıșta da dini inanca verilen önem arttıkça sahip olunan çocuk sayısının artmasının altında yatan sebebin; evlilik dışı çocuk sahibi olma, kısırlaştırma, kürtaj, doğum kontrolü gibi çocuk sahibi olmayı ertelettirecek davranışların yasaklanması olduğu söylenebilir.

$\mathrm{Bu}$ çalışmada analizlerde kullanılan değişkenlerin tanımlayıcı istatistikleri daha ayrıntılı bir şekilde Tablo 1'de sunulmuş̧ur.

Şekil 2. Dini inanışa verilen önem açısından sahip olunan ortalama çocuk sayıları

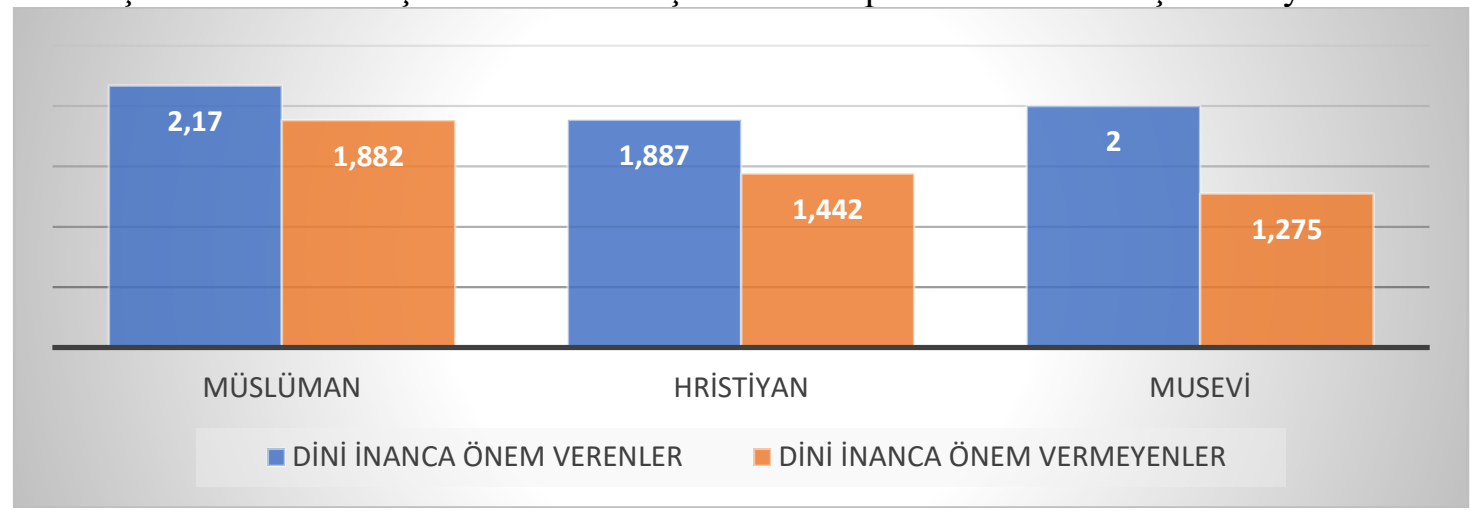

Kaynak: Dünya Değerler Anketi (2010-2014) verileri kullanılarak oluşturulmuştur. 
Tablo 1. Tanımlayıcı istatistikler

\begin{tabular}{|c|c|c|c|c|c|c|}
\hline & \multicolumn{2}{|c|}{ Müslüman } & \multicolumn{2}{|c|}{ Hristiyan } & \multicolumn{2}{|c|}{ Musevi } \\
\hline & Ortalama & Std.sapma & Ortalama & Std.sapma & Ortalama & Std.sapma \\
\hline Sahip olunan çocuk sayısı & 2.123 & 2.075 & 1.789 & 1.647 & 1.671 & 1.608 \\
\hline \multicolumn{7}{|l|}{ Dini İnanca Verilen Önem } \\
\hline Dini inanca Önem Verenler & 0.874 & 0.332 & 0.780 & 0.414 & 0.547 & 0.499 \\
\hline Dini İnanca Önem Vermeyenler (Temel sınıf) & 0.126 & 0.332 & 0.220 & 0.414 & 0.453 & 0.499 \\
\hline Dini Hizmetlere Katılma Sıklığı (Azalan) & 4.451 & 2.785 & 3.523 & 2.176 & 5.313 & 2.247 \\
\hline Dua Etme Sıklığ (Azalan) & 3.476 & 2.879 & 3.068 & 2.121 & 4.060 & 2.133 \\
\hline \multicolumn{7}{|l|}{ Cinsiyet } \\
\hline Kadın & 0.505 & 0.500 & 0.552 & 0.497 & 0.494 & 0.501 \\
\hline Erkek (Temel sinıf) & 0.495 & 0.500 & 0.448 & 0.497 & 0.506 & 0.501 \\
\hline \multicolumn{7}{|l|}{ Medeni durum } \\
\hline Evli/birlikte yaşıyor (Temel sınıf) & 0.655 & 0.475 & 0.616 & 0.486 & 0.626 & 0.485 \\
\hline Hiç Evlenmemiş & 0.278 & 0.448 & 0.232 & 0.422 & 0.317 & 0.466 \\
\hline Boşanmış/Dul/Ayrı & 0.068 & 0.251 & 0.152 & 0.359 & 0.057 & 0.232 \\
\hline \multicolumn{7}{|l|}{ Eğitim Düzeyi } \\
\hline İlk Okulu Yetersiz tamamlamış/Zorla Tamamlamış (Temel sınıf) & 0.184 & 0.387 & 0.160 & 0.367 & 0.091 & 0.288 \\
\hline Ortaöğretimi Tamamlamamış/Tamamlamış & 0.263 & 0.440 & 0.363 & 0.481 & 0.143 & 0.351 \\
\hline Üniversite Hazırlık Tamamlamış/Tamamlamamış & 0.299 & 0.458 & 0.219 & 0.414 & 0.260 & 0.440 \\
\hline $\begin{array}{l}\text { Üniversite Yüksek Eğitim Düşük Derece/Yüksek Eğitim Yüksek } \\
\text { Derece }\end{array}$ & 0.254 & 0.436 & 0.257 & 0.437 & 0.506 & 0.501 \\
\hline Gelir seviyesi (1: en düşük, 11: en yüksek seviye) & 5.257 & 1.975 & 4.753 & 2.038 & 5.411 & 1.889 \\
\hline Yaşam memnuniyeti (1: memnun değil, 10: memnun) & 6.747 & 2.289 & 6.926 & 2.252 & 7.147 & 1.955 \\
\hline Aileye verilen önem (1: önemli değil, 4 : çok önemli) & 3.947 & 0.274 & 3.921 & 0.316 & 3.913 & 0.295 \\
\hline Boş zamana verilen önem (1: önemli değil, 4: çok önemli) & 2.981 & 0.901 & 3.196 & 0.806 & 3.174 & 0.733 \\
\hline İşe verilen önem (1: önemli değil, 4 : çok önemli) & 3.601 & 0.746 & 3.553 & 0.763 & 3.536 & 0.657 \\
\hline \multicolumn{7}{|l|}{ Diğer insanlara duyulan güven } \\
\hline Güvenilir & 0.217 & 0.412 & 0.176 & 0.381 & 0.291 & 0.455 \\
\hline Dikkatli olunmalı (Temel sinıf) & 0.217 & 0.412 & 0.176 & 0.381 & 0.291 & 0.455 \\
\hline $\begin{array}{l}\text { Hanenin finansal durumundan duyulan memnuniyet (1: memnun } \\
\text { değil, 10: memnun) }\end{array}$ & 5.582 & 2.436 & 5.791 & 2.482 & 6.608 & 2.234 \\
\hline $\begin{array}{l}\text { Çocuğa iyi bir eğitim verememe endişesi (1:en düşük, 4: en } \\
\text { yüksek) }\end{array}$ & 1.916 & 1.034 & 1.930 & 1.090 & 1.826 & 0.896 \\
\hline $\begin{array}{l}\text { Kendini Mutlu Hissetme (Artan) } \\
\text { İș Durumu }\end{array}$ & 3.181 & 0.704 & 3.179 & 0.742 & 3.192 & 0.594 \\
\hline
\end{tabular}




\begin{tabular}{|c|c|c|c|c|c|c|}
\hline & \multicolumn{2}{|c|}{ Müslüman } & \multicolumn{2}{|c|}{ Hristiyan } & \multicolumn{2}{|c|}{ Musevi } \\
\hline & Ortalama & Std.sapma & Ortalama & Std.sapma & Ortalama & Std.sapma \\
\hline Tam Zamanlı Çalışan & 0.275 & 0.446 & 0.344 & 0.475 & 0.483 & 0.501 \\
\hline Parttime/ Kendi Hesab1 / Emekli & 0.304 & 0.460 & 0.372 & 0.483 & 0.283 & 0.451 \\
\hline Öğrenci/Ev Hanımı/İşsiz/Diğer (temel sınıf) & 0.421 & 0.494 & 0.283 & 0.451 & 0.234 & 0.424 \\
\hline \multicolumn{7}{|l|}{ Yaş } \\
\hline 18-28yaş(Temel sinıf) & 0.347 & 0.476 & 0.277 & 0.448 & 0.257 & 0.438 \\
\hline $29-35$ yaş & 0.187 & 0.390 & 0.156 & 0.363 & 0.162 & 0.369 \\
\hline $36-42$ yaş & 0.152 & 0.359 & 0.128 & 0.334 & 0.143 & 0.351 \\
\hline $43-50$ yaş & 0.143 & 0.351 & 0.132 & 0.338 & 0.151 & 0.359 \\
\hline $51-60$ yaş & 0.110 & 0.312 & 0.146 & 0.353 & 0.155 & 0.362 \\
\hline $61-98$ yaş & 0.062 & 0.241 & 0.161 & 0.367 & 0.132 & 0.339 \\
\hline \multicolumn{7}{|l|}{ Yaşanılan Yerin Nüfus Büyüklüğü } \\
\hline 2000 ve daha $\mathrm{Az}$ & 0.172 & 0.377 & 0.115 & 0.320 & 0.068 & 0.252 \\
\hline $2000-5000$ & 0.197 & 0.398 & 0.115 & 0.319 & 0.015 & 0.122 \\
\hline $5000-10000 / 10000-20000$ & 0.226 & 0.418 & 0.144 & 0.351 & 0.042 & 0.200 \\
\hline $20000-50000 / 50000-100000$ & 0.175 & 0.380 & 0.229 & 0.420 & 0.317 & 0.466 \\
\hline $100000-500000$ & 0.120 & 0.325 & 0.238 & 0.426 & 0.494 & 0.501 \\
\hline 500000 ve Daha Fazla(Temel sinıf) & 0.110 & 0.313 & 0.159 & 0.365 & 0.064 & 0.245 \\
\hline \multicolumn{7}{|l|}{ Sosyal Sınıf (1: en yüksek ve 5: en düşük) } \\
\hline İyi sosyal sinif (1 ve 2$)$ & 0.275 & 0.447 & 0.215 & 0.411 & 0.309 & 0.463 \\
\hline Orta sosyal sinif (3) & 0.337 & 0.473 & 0.353 & 0.478 & 0.343 & 0.476 \\
\hline Düşük sosyal sınıf (4 ve 5) (Temel sınıf) & 0.388 & 0.487 & 0.432 & 0.495 & 0.347 & 0.477 \\
\hline \multicolumn{7}{|l|}{ Anket y1lı } \\
\hline 2011 & 0.508 & 0.500 & 0.368 & 0.482 & 0.230 & 0.422 \\
\hline 2012 & 0.151 & 0.358 & 0.556 & 0.497 & 0.762 & 0.427 \\
\hline 2013 & 0.190 & 0.392 & 0.074 & 0.261 & 0.008 & 0.087 \\
\hline 2014(Temel sinif) & 0.151 & 0.358 & 0.002 & 0.042 & 0.000 & 0.000 \\
\hline Örnek hacmi & 10203 & & 17753 & & 265 & \\
\hline
\end{tabular}




\subsection{Bulgular}

Bu çalışmada, Dünya Değerler Anketi (World Values Survey) 2010- 2014 verileri kullanılarak Müslüman, Hristiyan ve Musevi dini inanışa sahip kişilerin doğurganlıklarını etkileyen faktörler etkileşim hipotezi açısından sayma veri regresyon modeli ile araştırılmıştır. Analizlerde yayılım parametresi olan $\sigma^{2}$ değerinin 1'den büyük çıkmasından dolayı aşırı yayılım ile karşılaşılmış ve Müslüman ile Hristiyan inanışını benimseyenler için oluşturulan modellerde Negatif Binom regresyon modeli ve Museviler için yayılım parametresi olan $\sigma^{2}$ değerinin 1 'den küçük çıktığ 1 için eksik yayılımın varlığından dolayı din ve doğurganlık arasındaki ilişkiyi analiz etmek için Robust Poisson regresyon modelinden faydalanılmıştır. Tablo 2'de her üç inanışa göre elde edilen doğurganlık model tahmin sonuçları yer almaktadır.

Elde edilen sonuçlara göre, Müslüman bireylerde dini inanca önem verenler, önem vermeyenlere göre 0.003 kat daha fazla çocuğa sahip iken Hristiyanlarda bu oran 0.057 kat daha fazladır. Musevilerde ise bu değişkenin anlamlı olmadığı görülmektedir. Ayrıca her üç dini inanca göre de bireylerin dua etme sıklığı azaldıkça sahip oldukları çocuk sayısı da azalmaktadır. Medeni durum değiş̧keni incelendiğinde, Müslümanlarda boşanmış, dul ya da ayrı yaşayanların evli ya da birlikte yaşayanlara göre 0,13 kat daha az çocuğa sahip oldukları görülürken biç evlenmemiş olanların evli ya da birlikte yaşayanlara göre her üç dini inanışta da daha fazla çocuğa sahip oldukları görülür. Bireylerin eğitim durumu incelendiğinde eğitim düzeyi arttıkça sahip olunan çocuk sayısının azaldığı, en fazla azalışın üniversite ve üzeri eğitim görenlerde olduğu söylenebilir. Chamie (1977)'nin çalışmasında da olduğu gibi sadece dini göstergeler değil sosyoekonomik göstergelerden birisi olan eğitim düzeyi de doğurganlık üzerinde etki yaratmakta ve bu etki beklenildiği gibi azaltıcı yönde olmaktadır. Bireyin gelir seviyesi Müslüman ve Musevilerde sahip olunan çocuk sayısı üzerinde etkili değil iken Hristiyanlarda gelir arttıkça sahip olunan çocuk sayısı 0.012 kat azalmaktadır. Boş zamana verilen önem arttıkça Müslüman ve Hristiyanlarda sahip olunan çocuk sayısının azaldığı ve Hristiyanlarda bu azalışın 2 kat daha fazla olduğu görülür. Dahil olunan sosyal sınıf incelendiğinde Müslüman ve Hristiyanlarda orta sosyal sınıfa dahil olanların alt sosyal sınıftakilere göre daha az çocuğa sahip oldukları görülürken Musevilerde tersine bir etki söz konusudur. İnsanlara duyulan güven her üç dini inanışa göre de çocuk sayısı üzerinde anlamlı bir etkiye sahip değildir. Hanenin finansal durumundan duyulan memnuniyet değişkeni sahip olunan çocuk sayısı üzerinde hem Müslümanlarda hem de Hristiyanlarda anlamlı ve pozitif bir etkiye sahiptir. Ayrıca çocuğa iyi bir eğitim verememe endişesi arttıkça sahip olunan çocuk sayısı Müslümanlarda 0,014 kat azalırken Hristiyanlarda bu azalış 0.084 kat kadardır. Yaşam memnuniyetinin artması Müslümanlarda anlamlı bir etkiye sahip değilken Hristiyan ve Musevilerde çocuk sayısını arttırıcı etki yaratmaktadır. Müslüman bireylerde tam zamanlı çalışanların öğrenci, ev hanımı, işsiz ve diğer çalışanlara göre çocuk sayısı 0.082 kat daha az iken Hristiyanlarda bu oran yaklaşık iki katı daha azdır. Yaşanılan yerin nüfus büyüklüğ̈̈ arttıkça sahip olunan çocuk sayısının Müslümanlarda azaldığı görülmektedir. Musevilerde ise nüfusun sahip olunan çocuk sayısı üzerinde anlamlı bir etkisi görülmemiştir.

Tablo 2'den de görüldüğü gibi Müslüman ve Hristiyanlarda 2014 yılına göre tüm diğer yıllarda çocuk sayısında bir azalma söz konusu olmuştur. Müslüman ve Hristiyan dini inanışlarında din ile ilgili göstergelerin hepsinin anlamlı ve inanışın ön gördüğü ideolojiyle yani kürtajın ve doğum kontrolün yasaklanmasının çocuk sayısını arttırması ile aynı yönde etki yaratması, diğer taraftan bu inanışlara sahip olanların çocuk sayıları üzerinde eğitim düzeyi, gelir, dahil olunan sosyal çevre, yaşanılan yerin büyüklüğü gibi değişkenlerin de etkili olması dini inanışla beraber sosyo-ekonomik göstergelerin de doğurganlık üzerinde etkili olduğunu göstermektedir. 
Tablo 2. Sayma veri regresyon modellerine ait tahmin sonuçları

\begin{tabular}{|c|c|c|c|c|c|c|}
\hline & \multirow{2}{*}{\multicolumn{2}{|c|}{$\begin{array}{c}\text { Negatif Binom Reg. Model } \\
\text { Müslüman }\end{array}$}} & \multirow{2}{*}{\multicolumn{2}{|c|}{$\begin{array}{c}\text { Negatif Binom Reg. Model } \\
\text { Hristiyan }\end{array}$}} & \multirow{2}{*}{\multicolumn{2}{|c|}{$\begin{array}{c}\text { Robust Poisson Reg. Model } \\
\text { Musevi }\end{array}$}} \\
\hline & & & & & & \\
\hline & Katsay1(z) & Marjinal etki & Katsay1(z) & Marjinal etki & Katsay1(z) & Marjinal etki \\
\hline \multicolumn{7}{|l|}{ Dini İnanca Verilen Önem } \\
\hline Dini inanca Önem Verenler & $0.046(1.94) * * *$ & 0.033 & $0.046(2.73) *$ & 0.057 & $0.100(1.27)$ & 0.051 \\
\hline Dini Hizmetlere Katılma Sıklığı (Azalan) & $-0.007(-2.31)^{* *}$ & -0.006 & $-0.014(-4.18) *$ & -0.018 & $0.005(0.27)$ & 0.003 \\
\hline Dua Etme S1klığ 1 (Azalan) & $-0.015(-4.58)^{*}$ & -0.011 & $-0.018(-4.65)^{*}$ & -0.022 & $-0.024(-1.18)$ & -0.012 \\
\hline \multicolumn{7}{|l|}{ Cinsiyet } \\
\hline Kadin & $0.047(2.82)^{*}$ & 0.035 & $0.021(1.69)^{* * *}$ & 0.026 & $0.018(0.24)$ & 0.009 \\
\hline \multicolumn{7}{|l|}{ Medeni durum } \\
\hline Hiç Evlenmemiş & $-4.112(-35.18 *)$ & -2.285 & $-1.766(-51.56)^{*}$ & -1.553 & $-3.725(-5.00)^{*}$ & -1.611 \\
\hline Boşanmış/Dul/Ayrı & $-0.194(-7.54)^{*}$ & -0.132 & $-0.102(-6.53)^{*}$ & -0.122 & $-0.179(-1.69)^{* * *}$ & -0.084 \\
\hline \multicolumn{7}{|l|}{ Eğitim Düzeyi } \\
\hline Ortaöğretimi Tamamlamamış/Tamamlamış & $-0.077(-3.74)^{*}$ & -0.056 & $-0.198(-12.80)^{*}$ & -0.240 & $-0.230(-2.05)^{* *}$ & -0.108 \\
\hline Üniversite Hazırlık Tamamlamış/Tamamlamamış & $-0.107(-5.12)^{*}$ & -0.078 & $-0.252(-14.13)^{*}$ & -0.293 & $-0.421(-3.86)^{*}$ & -0.194 \\
\hline $\begin{array}{l}\text { Üniversite Yüksek Eğitim Düşük Derece/Yüksek } \\
\text { Eğitim Yüksek Derece }\end{array}$ & $-0.152(-6.59)^{*}$ & -0.109 & $-0.321(-16.73)^{*}$ & -0.371 & $-0.536(-3.76)^{*}$ & -0.276 \\
\hline Gelir seviyesi (1: en düşük, 11: en yüksek seviye) & $0.005(1.20)$ & 0.004 & $-0.010(-3.07)^{*}$ & -0.012 & $-0.027(-1.20)$ & -0.014 \\
\hline $\begin{array}{l}\text { Yaşam memnuniyeti (1: memnun değil, 10: } \\
\text { memnun) }\end{array}$ & $0.004(1.01)$ & 0.003 & $0.005(1.74)^{* * *}$ & 0.006 & $0.051(2.39)^{* *}$ & 0.026 \\
\hline $\begin{array}{l}\text { Aileye verilen önem (1: önemli değil, 4: çok } \\
\text { önemli) }\end{array}$ & $0.093(3.03) *$ & 0.069 & $0.082(3.95)^{*}$ & 0.102 & $-0.119(-1.13)$ & -0.060 \\
\hline $\begin{array}{l}\text { Boş zamana verilen önem (1: önemli değil, } 4 \text { : çok } \\
\text { önemli) }\end{array}$ & $-0.016(-2.15)^{* *}$ & -0.012 & $-0.019(-2.71)^{*}$ & -0.024 & $0.009(0.18)$ & 0.004 \\
\hline İşe verilen önem (1: önemli değil, 4: çok önemli) & $-0.006(-0.63)$ & -0.004 & $0.050(6.03)^{*}$ & 0.062 & $0.024(0.53)$ & 0.012 \\
\hline \multicolumn{7}{|l|}{ Diğer insanlara duyulan güven } \\
\hline Güvenilir & $0.019(1.17)$ & 0.014 & $-0.023(-1.43)$ & -0.028 & $0.082(0.83)$ & 0.042 \\
\hline $\begin{array}{l}\text { Hanenin finansal durumundan duyulan } \\
\text { memnuniyet (1: memnun değil, 10: memnun) }\end{array}$ & $-0.006(-2.17)^{* *}$ & -0.005 & $-0.006(-2.27)^{* *}$ & -0.007 & $-0.022(-0.96)$ & -0.011 \\
\hline $\begin{array}{l}\text { Çocuğa iyi bir eğitim verememe endişesi (1: en } \\
\text { düşük, 4: en yüksek) }\end{array}$ & $-0.018(-2.63)^{*}$ & -0.014 & $-0.067(-11.56)^{*}$ & -0.084 & $-0.017(-0.45)$ & -0.009 \\
\hline $\begin{array}{l}\text { Kendini Mutlu Hissetme (Artan) } \\
\text { İş Durumu }\end{array}$ & $0.029(2.47)^{* *}$ & 0.021 & $0.049(5.66)^{*}$ & & $0.089(1.36)$ & 0.045 \\
\hline Tam Zamanlı Çalışan & $-0.113(-5.53)^{*}$ & -0.082 & $-0.117(-6.94)^{*}$ & -0.143 & $0.147(1.33)$ & 0.075 \\
\hline Parttime/Kendi Hesabına/Emekli & $-0.016(-0.89)$ & -0.012 & $-0.050(-3.35)^{*}$ & -0.062 & $0.215(1.84)^{* * *}$ & 0.115 \\
\hline
\end{tabular}




\begin{tabular}{|c|c|c|c|c|c|c|}
\hline & \multirow{2}{*}{\multicolumn{2}{|c|}{$\begin{array}{c}\text { Negatif Binom Reg. Model } \\
\text { Müslüman }\end{array}$}} & \multirow{2}{*}{\multicolumn{2}{|c|}{$\frac{\text { Negatif Binom Reg. Model }}{\text { Hristiyan }}$}} & \multirow{2}{*}{\multicolumn{2}{|c|}{$\begin{array}{c}\text { Robust Poisson Reg. Model } \\
\text { Musevi }\end{array}$}} \\
\hline & & & & & & \\
\hline & Katsay1(z) & Marjinal etki & Katsayı(z) & Marjinal etki & Katsayı(z) & Marjinal etki \\
\hline \multicolumn{7}{|l|}{ Yaş } \\
\hline \multicolumn{7}{|l|}{ 18-28yaş } \\
\hline $29-35$ yaş & $0.471(16.52)^{*}$ & 0.409 & $0.497(19.84)^{*}$ & 0.741 & $0.725(1.66)^{* * *}$ & 0.480 \\
\hline $36-42$ yaş & $0.738(26.49)^{*}$ & 0.724 & $0.761(30.77)^{*}$ & 1.286 & $1.081(2.68)^{*}$ & 0.845 \\
\hline $43-50$ yaş & $0.851(30.71)^{*}$ & 0.881 & $0.865(35.41)^{*}$ & 1.524 & $1.146(2.83)^{*}$ & 0.915 \\
\hline $51-60$ yaş & $0.980(34.37)^{*}$ & 1.109 & $0.932(38.45)^{*}$ & 1.670 & $1.210(2.97)^{*}$ & 0.989 \\
\hline $61-98$ yaş & $1.170(36.60)^{*}$ & 1.533 & $1.015(39.81)^{*}$ & 1.859 & $1.347(3.25)^{*}$ & 1.208 \\
\hline \multicolumn{7}{|c|}{ Yaşanılan Yerin Nüfus Büyüklüğü } \\
\hline 2000 ve Daha Az & $0.193(6.76)^{*}$ & 0.153 & $0.021(0.95)$ & 0.026 & $0.240(0.91)$ & 0.135 \\
\hline $2000-5000$ & $0.154(5.60)^{*}$ & 0.119 & $0.048(2.18)^{* *}$ & 0.061 & $0.135(0.41)$ & 0.073 \\
\hline $5000-10000 / 10000-20000$ & $0.099(3.40)^{*}$ & 0.075 & $0.034(1.62)$ & 0.043 & $-0.299(-0.92)$ & -0.133 \\
\hline $20000-50000 / 50000-100000$ & $0.131(4.60)^{*}$ & 0.102 & $0.055(2.88)^{*}$ & 0.069 & $0.035(0.20)$ & 0.018 \\
\hline $100000-500000$ & $0.117(3.88)^{*}$ & 0.091 & $0.000(-0.02)$ & 0.000 & $-0.051(-0.28)$ & -0.026 \\
\hline \multicolumn{7}{|c|}{ Sosyal Sınıf (1: en yüksek ve 5 : en düşük) } \\
\hline İyi sosyal sinif (1 ve 2$)$ & $-0.059(-2.99)^{*}$ & -0.043 & $-0.021(-1.23)$ & -0.026 & $0.086(0.77)$ & 0.045 \\
\hline Orta sosyal sinif (3) & $-0.042(-2.56)^{* *}$ & -0.031 & $-0.028(-2.14)^{* *}$ & -0.035 & $0.122(1.79)^{* * *}$ & 0.063 \\
\hline \multicolumn{7}{|l|}{ Anketin yapıldığ 1 yıl } \\
\hline 2011 & $-0.284(-12.92)^{*}$ & -0.212 & $-0.396(-3.69)^{*}$ & -0.471 & $0.693(1.50)$ & 0.432 \\
\hline 2012 & $-0.081(-3.28)^{*}$ & -0.059 & $-0.201(-1.88) * * *$ & -0.254 & $0.564(1.17)$ & 0.250 \\
\hline 2013 & $-0.396(-15.30)^{*}$ & -0.261 & $-0.203(-1.87) * * *$ & -0.232 & $0.000(0.00)$ & 0.00 \\
\hline Sabit & $0.272(2.04)^{* *}$ & & $0.227(1.58)$ & & $-0.661(-0.86)$ & \\
\hline Pearson $\chi^{2}$ istatistiğ $i$ & 15009.2 & & 17941 & & 121.0253 & \\
\hline$\sigma^{2}$ & 1.476 & & 1.012 & & 0.526 & \\
\hline
\end{tabular}

Not: ${ }^{*} \mathrm{p}<.01, * * \mathrm{p}<.05, * * * \mathrm{p}<.10$ olarak alınmıştır 


\section{Sonuç}

$\mathrm{Bu}$ çalışmada, sayma veri regresyon modelleri kullanılarak farklı dini inanışlara sahip bireylerin doğurganlık davranışını etkileyen faktörler Müslüman, Hristiyan ve Musevi dini inanışlar açısından incelenmiştir. Her üç inanışta da hem bireyin hem de toplumun yaşam tarzlarını belirlemeye ve düzenlemeye yönelik evlenmeden birlikteliğin ve çocuk sahibi olmanın yasaklanması, kürtaj, kısırlaştırma gibi doğum kontrol tekniklerinin ve yöntemlerinin yasaklanması gibi kesin kurallar yer almaktadır. Analizlerden elde edilen bulgulara göre, her üç inanışta da evlilik dışı çocuk dünyaya getirilmesi yasaklandığı göz önüne alındığında, hiç evlenmemiş, boşanmış, dul ayrı yaşamanın evli ya da beraber yaşayanlara göre daha az çocuk sahibi oldukları görülür. Müslümanlarda dini inanca önem verenler, önem vermeyenlere göre daha fazla çocuk sahibidir. Hristiyanlarda bu değişkenin etkisinin daha fazla olduğu görülürken Musevilerde ise anlamlı olmadığı görülmektedir. Yine Müslüman ve Hristiyan dini inancına sahip olanlarda dua etme sıklığı ile çocuk sayısı arasında anlamlı ve doğru yönlü bir ilişkinin olduğu gözlenirken Musevilerde bu değişkenin anlamlı değildir. Eğitim düzeyinde artışın meydana gelmesi sahip olunan çocuk sayısı üzerinde azaltıcı etkiye sebep olmakla birlikte en fazla azalışın üniversite ve üzeri eğitim görenlerde olduğu söylenebilir. Eğitim düzeyinin artması dinlerin evlilik dışı çocuk dünyaya getirmeyi yasaklamalarıyla birleştiğinde, Adsera (2004)'nın çalışmasında da belirtildiği gibi, kişilerin çocuk sahibi olmaya ilişkin zamanı ertelemelerine sebep olmakta ve çocuk sayısını azaltmaktadır. Ayrıca yaşanılan yerin büyüklüğünün artması genel olarak bütün modellerde çocuk sayısının azalmasına sebep olmaktadır. Daha fazla nüfusa sahip olan yerleşim yerlerinde kişilerin toplumsal yapıda daha fazla bireyselleşmesi, doğum kontrolüne ilişkin olanaklara erişiminin kolaylaşması, evlenme yaşını belirleyen sosyal güçlerin olmaması gibi kişilerin özel yaşamlarındaki tabuların ortadan kalkması Becker (1960)'ın çalışmasında yer alan ve kişilerdeki "karar verme odası" olarak adlandırılan mekanizmanın rahatlamasına sebep olmaktadır.

$\mathrm{Bu}$ çalışmadan elde edilen bulgular, Müslüman ve Hristiyan dini inanışında hem din hem de sosyo-ekonomik değişkenlerin doğurganlık üzerinde etkili olmasından dolayı etkileşim hipotezinin, Musevilik dini inanışında ise dini göstergelerin çok fazla anlamlı etkiye sahip olmaması ve sosyo-ekonomik değişkenlerin doğurganlık üzerinde daha fazla etkili olmasından dolayı karakteristikler hipotezinin geçerli olduğunu destekler niteliktedir.

\section{Kaynakça}

Adsera, A. (2006). Marital fertility and religion: Recent changes in Spain. Population Studies, 60(2), 205-221.

Adsera, A. (2006). Religion and changes in family-size norms in developed countries. Review of Religious Research, 47(3), 271-286.

Arı, A. ve Önder, H. (2013). Farklı veri yapılarında kullanılabilecek regresyon yöntemleri. Anadolu Tarım Bilimleri Dergisi, 3(28), 168-174.

Bar-El, R., Muñoz, T. G., Neuman, S., ve Tobol, Y. (2013). The Evolution of secularization: Cultural transmission, religion and fertility - theory, simulations and evidence. (J. Zhang, Dü.) Journal of Population Economics, 26, 1129-1174.

Baudin, T. (2015). Religion and fertility: The French connection. Demographic Research, 32, 397-420, DOI: 10.4054/DemRes.2015.32.13

Bauer, T., Million, A., Rotte, R., ve Zimmermann, K. F. (1999). Immigrant labor and workplace safety. IZA, Discussion Paper No: 16.

Breslow, N. E.(1990). Tests of hypotheses in overdispersed Poisson regression and other QuasiLikelihood models. Journal of the American Statistical Association, 85 (410), 565-571. 
Carrivick, P. J. W., Lee, A. H. ve Yau, K. K. W. (2003). Zero- Inflated Poisson modelling to evaluate occupational safety intervention. Safety Science, 41, 53-63.

Becker, G. S. (1960). An economic analysis of fertility. In: Demographic and economic change in developed countries. Conference of the Universities-National Bureau Committee for Economic Research, a Report of the National Bureau of Economic Research. Princeton: Princeton University Press, pp 209-240.

Becker, G. S. (2009). A treatise on the family. London: Harvard University Press.

Becker, G. S. ve Lewis, H. G. (1973). On the interaction between the quantity and quality of children. Journal of Political Economy, 2 (82), 279-288.

Cameron, A. C. ve Trivedi, P. K. (1986). Econometrics models based on count data: Comparison and applications of some estimators and tests. Journel of Applied Econometrics, (1), 29-53.

Chamie, J. (1977). Religious differentials in fertility: Lebanon, 1971. Population Studies, 31(2), 365-382.

Chamie, J. (1981). Religion and fertility: Arab Christian-Muslim differentials. Cambridge: Cambridge University Press.

Cohen-Zada, D. ve Sander, W. (2008). Religion, religiosity and private school choice: Implicationsfor estimating the effectiveness of private schools. Journal of Urban Economics 64, 85-100.

Dean, C., B. (1992). Testing for overdispersion in poisson and binomial regression models. Journal of the American Statistical Association, 87(418), 451457, DOI: 10.1080/01621459.1992.10475225

Engle, R. ve Granger, C. (1987). Co-integration and error correction: Representation, estimation, and testing. Econometrica, 55(2), 251-276.

Heaton, T. B. (2011). Does religion influence fertility in developing countries. Population Research and Policy Review, 30, 449-465.

Heineck, G. (2006). The relationship between religion and fertility: Evidence for Austria. Papers on Economics of Religion 06/01, Department of Economic Theory and Economic History of the University of Granada.

Jones, G. W. (2006). A demographic perspective on the muslim world. Journal of Population Research, 23(2), 243-265.

Karaoğlan, S. ve Duman, M. Z. (2017). Dini inanç ve tutumların doğurganlık üzerindeki etkileri (Van ili örneği). Uluslararası Sosyal Araştırmalar Dergisi, 10(50), 392-404.

Lehrer, E. L. (1996). The role of the husband's religious affiliation in the economic and demographic behavior of families. Journal for the Scientific Study of Religion, 35(2), 145-155.

Lee, A. H., Stevanson, M. R., Wang, K., ve Yau, K. K. W. (2002). Modelling young driver motor vehicle crashes: Data with extra zeros. Accident Analysis and Prevention, 34, 515-521.

Marcum, J. P. (1981). Explaining fertility differences among U.S. Protestants. Social Forces, $60(2), 532-542$.

McQuillan, K. (2004). When does religion influence fertility? Population and Development Review, 30(1), 25-56.

Rock, S., Sedo, S. ve Willenborg, M. (2001). Analyst following and count data econometrics. Journal of Accounting and Economics, 30, 351-373. 
Selim, S. ve Üçdoğruk, Ş. (2003). Sayma veri modelleri ile çocuk sayısını belirleyicileri: Türkiye'deki Seçilmiş iller için sosyoekonomik analizler. Dokuz Eylül Üniversitesi İ.I.B.F Dergisi, 2(18), 13-31.

Selim (2004). Türkiye'de çocuk talebi ve kadınların işgücüne katılımının doğurganlık üzerindeki etkisi: Ekonometrik yaklaşım, Dokuz Eylül Üniversitesi, Sosyal Bilimler Enstitüsü, (Yayımlanmamış doktora tezi), İzmir.

Sezgin, F. H. ve Deniz, E. (2004). Poisson regresyon modelinde aşırı yayılım durumu ve Negatif Binomial Regresyon analizinin Türkiye grev sayıları üzerine bir uygulaması. Yönetim, 48, 1725.

Silva, J. M. C. S. (1997). Unobservables in count data models for on-site samples. Economic Letters, 54, 217-220.

Wang, W. ve Famoye, F. (1997). Modelling household fertility decisions with Generalized Poisson Regression. Journal of Population Economics, 10, 273-283.

Winkelmann, R. (2008). Econometric analysis of count data. Springer.

World Values Survey, WVS (2010-2014) Data Set.

Zhang, L. (2008). Religious affiliation, religiosity, and male and female fertility. Demographic Research, 18(8), 233-261.

ETIKK ve BİLIMSEL İLKELER SORUMLULUK BEYANI

$\mathrm{Bu}$ çalışmanın tüm hazırlanma süreçlerinde etik kurallara ve bilimsel atıf gösterme ilkelerine riayet edildiğini yazar(lar) beyan eder. Aksi bir durumun tespiti halinde Afyon Kocatepe Üniversitesi Sosyal Bilimler Dergisi’nin hiçbir sorumluluğu olmayıp, tüm sorumluluk makale yazarlarına aittir. 